\title{
BIALORUSINI NA BLISKIM WSCHODZIE WOBEC SPRAW POLSKICH W LATACH 1941-1945 W ŚWIETLE PISM KS. MICHALA BOŻERIANOWA
}

Wśród polskich cywilów ewakuowanych wraz z Armią Andersa z ZSRR w 1942 r. było ponad 2 tysiące Białorusinów wyznania prawosławnego. $Z$ uwagi na fakt, że władze sowieckie nie chciały wypuścić osoby narodowości niepolskiej znaczna część Białorusinów podawała się za Polaków i katolików. Ukrywając swoje swe pochodzenie część Białorusinów dokonało konwersji na katolicyzm.

Pomoc emigracyjnego rządu polskiego w wyjeździe $\mathrm{z}$ ZSRR wywołała wśród Białorusinów propolskie sympatie i wyrazy wdzięczności. Przy pomocy Franciszka Wilka, członka Rady Narodowej w Iranie w 1942 r. powstał Komitet Białoruski z ks. Michałem Bożerianowem na czele. Komitet wydał kilka memoriałów i odezw do rządu polskiego i amerykańskiego, w których negatywnie oceniono włączenie województw północnowschodnich II RP do ZSRR we wrześniu 1939 r. Większość Białorusinów deklarowała chęć pozostania obywatelami państwa polskiego. Taką postawę uchodźców białoruskich należy tłumaczyć brakiem innej perspektywy na przyszłość. Jednym z postulatów, które wysuwał przewodniczący Komitetu Białoruskiego ks. M. Bożerianów było wprowadzenie przedstawiciela mniejszości białoruskiej do polskiej Rady Narodowej w Londynie. Słabościa Komitetu był jego skład osobowy i zaplecze. Uchodźcy białoruscy posiadali nieliczną inteligencję - przeważnie byli to duchowni i nauczyciele - pozbawieni jakiegokolwiek doświadczenia w działalności politycznej. Większość Białorusinów było chłopskiego pochodzenia lub byli pracownikami służb leśnych.

W 1943 r. większość uchodźców białoruskich przeniosło się do Afryki Wschodniej. Tam pogorszyły się relacje wśród uchodźców a zwłaszcza między prawosławnymi a katolikami. Pomimo, że większość uchodźców narodowości białoruskiej byli nastawieni propolsko to wśród Polaków umacniał się stereotyp o ich antypolskiej postawie. Ta niczym nieugruntowana antybiałoruska fobia Polaków doprowadziła do konfliktów wyznaniowych w obozach uchodźców. Konflikty religijne, trwające do zamknięcia obozów w Afryce i śmierć propolsko nastawianego przywódcy Komitetu Białoruskiego ks. Michała Bożerianowa spowodowała, że większość przebywających tam Białorusinów zmieniała swe nastawienie z pozytywnego do Polski na niechętną postawę do współpracy z Polakami.

Słowa kluczowe: Białorusini, Michał Bożerianow, emigracja.

Dzieje społeczności białoruskiej na emigracji w okresie II wojny światowej są mało znane $^{2}$. Powstałe na emigracji opracowania mają charakter bardziej wspomnieniowy i nie

\footnotetext{
${ }^{1}$ Prof. zw. dr hab. Antoni Mironowicz, kierownik Katedry Historii Europy Środkowo-Wschodniej Uniwersytetu w Białymstoku. amir@uwb.edu.pl

${ }^{2}$ W. Wróblewski, Duszpasterstwo mniejszości religijnych $w$ Wojsku Polskim w latach 1918-1939, [w:] Białoruś, Czechosłowacja, Litwa, Polska, Ukraina. Mniejszości w świetle spisów statystycznych XIX-XX w., pod red. J. Skarbka, Lublin 1996, s. 104-105; Z. Waszkiewicz, Duszpasterstwo w sitach zbrojnych Drugiej Rzeczypospolitej (1918-1939), Toruń 2000, s. 136-139. Por. również prace J. Odziemkowskiego, Stużba duszpasterska Wojska Polskiego 1914-1945, Warszawa 1998 i J.
} 
poddają szerszej analizie zagadnienia postaw mniejszości narodowych wobec państwa polskiego. Jeszcze trudniej jest przedstawić postawę mniejszości narodowych wobec spraw polskich na emigracji w czasie II wojny światowej. Ocena rzeczywistości na emigracji, tuż po klęsce wrześniowej, miała charakter emocjonalny ale oddawała rzeczywiste odczucia Białorusinów, Ukraińców, Rosjan, obywateli II Rzeczypospolitej. Opinia ta jest tym cenniejsza albowiem wyrażona jest przez środowiska, które Polskę traktowali przed i po 1939 r. jako swoją ojczyznę.

Szczególnie wartościowym źródłem oceniającym politykę władz RP i polskich sił politycznych na emigracji wobec mniejszości narodowych ma broszura ks. Michała Bożerianowa Moja odpowiedź ,,ludziom małym”. Autor broszury podpisał się jako Prawosławnej Cerkwi Polskiej Inspektor Religijny na Centralną i Wschodnią Afrykę. Broszurę wydano na jesieni 1945 r. w Tengeru koło Arusha w Tanzanii (Tanganyika).

Stosunek Białorusinów do państwa polskiego został wyrażony przez uchodźców, którzy przybyli z terenów Związku Radzieckiego w 1942 roku do Iranu. Wraz z żołnierzami generała Władysława Andersa wyjechało wielu cywilów, należących do mniejszości narodowych. Cywile, przeważnie kobiety, starcy i dzieci, poprzez port w Krasnowodsku, statkami dotarli do irańskiego portu Pechlewi, a stamtąd do Teheranu. Żołnierze zostali skierowani do Iraku lub Palestyny i otoczeni opieką duszpasterską ordynariatu polowego.

Odmienny okazał się los cywilów, przeważnie członków rodzin żołnierzy, którzy musieli opuścić Iran. Ci, którzy mieszkali na terenie Teheranu i okolic zostali wywiezieni do różnych krajów świata. Część z nich trafiła do Indii, Nowej Zelandii, Palestyny, Libanu, Meksyku, Tanzanii (ówczesna Tanganika), Rodezji, Ugandy, Afryki Południowej i do innych krajów kontynentu afrykańskiego. Wśród 17375 obywateli polskich, którzy trafili do osiemnastu obozów w Afryce 6964 pochodziło z województw wschodnich II Rzeczypospolitej. Z województwa białostockiego było 1863 uchodźców, wileńskiego 1378 , nowogródzkiego 1753 i poleskiego 1 970. Znaczny odsetek z nich stanowili Białorusini wyznania prawosławnego ${ }^{3}$. Opiekę duchową nad nimi sprawował prawosławny duchowny ksiądz Michał Bożerianow (1911-1946) ${ }^{4}$.

Ksiądz Michał Bożerianow urodził się 5 listopada 1911 roku w Wilnie w rodzinie duchownej. Dziadek jego Aleksander Michajłowicz Bożerianow, generał armii carskiej, uczestnik ostatniej wojny krymskiej. Ojciec jego Aleksander był właścicielem ziemskim na Wileńszczyźnie i Nowogródczyźnie. Ksiądz Michał Bożerianow wyrastał w atmosferze wielowyznaniowego i wielokulturowego Wilna. Michał Bożerianow był człowiekiem bardzo energicznym, dobrze wykształconym, o wysokiej kulturze osobistej. W Wilnie wstąpił, po zdaniu matury, na Wydział Matematyczno-Przyrodniczy i został

Odziemkowskiego i S. Frątczak, Polskie duszpasterstwo wojskowe, Warszawa 1996; A. Mironowicz, Polskie prawostawne duszpasterstwo cywilne w Afryce, „Wiadomości PAKP”, nr 5 (138), Warszawa 2001, s. 12-17; bp. Miron, Z dziejów prawosławnego ordynariatu wojskowego w Rzeczypospolitej, [w:] Chrześcijaństwo - Kościót - Prawosławie, Białystok 2003. Uzupełnieniem do tych opracowań książkowym są liczne artykuły zamieszczone w kwartalniku „Polski Żołnierz Prawosławny" wydawany przez Prawosławny Ordynariat Wojska Polskiego w latach 1994-2014.

${ }^{3}$ J. Grzybowski, Białorusini w polskich regularnych formacjach wojskowych $w$ latach 1918-1945, Warszawa 2006, s. 380.

${ }^{4}$ M. Szwedziuk, Bełarusy u Afrycy w $1942-1948$ godach, „Bełarus” nr 450, Nju Jork 1998. Przedruk Białorusini w Afryce w latach 1942-1948, „Polski Żołnierz Prawosławny”, R V, nr 2(15), 1998, s. 14; Betarusy u Afrycy w 1942-1948 godach, „Ruń”, nr 29, Wilno 2000. 
studentem Uniwersytetu Stefana Batorego. Po ukończeniu studiów zdał do seminarium prawosławnego w Warszawie. Święcenia kapłańskie otrzymał z rąk metropolity Dionizego w 1935 roku. Początkowo został skierowany do działalności misyjnej na Łemkowszczyźnie. Działalnością misyjną wśród Łemków kierował wówczas ksiądz Grzegorz Pawliszin. Pierwszą parafię o. Bożerianow objął w 1936 roku we wsi Tichanie, powiatu małopolskiego.

Z akt personalnych, znajdujących się w Archiwum Metropolii Prawosławnej PAKP wynika, że Michał Bożerianow 5 stycznia 1937 roku został proboszczem cerkwi pw. św. św. Kosmy i Damiana w Skwirtnem, w powiecie gorlickim ${ }^{5}$. Decyzją metropolity Dionizego ksiądz Bożerianow został 2 maja 1937 r. nagrodzony „nabedrennikom”6. Wkrótce ksiądz Michał 3 czerwca 1937 roku poprosił Warszawsko-Chełmski Duchowny Konsystorz Prawosławny o udzielenie mu miesięcznego urlopu ${ }^{7}$. Ostatecznie duchowny uzyskał urlop w dniach od 22 czerwca do 10 lipca 1937 roku $^{8}$. W takcie urlopu 7 lipca duchowny uzyskał zgodę metropolity Dionizego na przejście do innej diecezji ${ }^{9}$. We wsi Jatwiesk w pobliżu Grodna mieszkała jego rodzina. Czy były inne przyczyny wyjazdu duchownego z misji łemkowskiej - nie wiadomo. Parafię w Skwirtnem ks. Michał Bożerianow opuścił na początku września 1937 roku. Po wyjeździe proboszcza świątynia w latach wojny popadła w ruinę. Z raportu księdza Michała Popiela z 23 września 1946 roku skierowanego do Warszawskiego Konsystorza Prawosławnego wynika, że w Skwirtnem „dom parafialny drewniany bez drzwi i okien, i bez pieców. Świątynia formalnie zdewastowana bez drzwi i okien, i bez podłogi. Tak jak była budowana ze starego drzewa, teraz nie da się odprawować. Żadnych innych rzeczy nie ma"10.

Na własną prośbę ksiądz Michał Bożerianow został przyjęty 15 września 1937 roku do eparchii poleskiej. Tam powierzono mu obsługiwanie cerkwi w Werstoku ${ }^{11}$. W okresie międzywojennym cerkiew werstocka nie otrzymała statusu prawnego parafii ani filii i była nieetatową cerkwią parafii w Omelańcu, trzeciego dekanatu powiatu brzeskiego, diecezji poleskiej $^{12}$. Z Werstoku ksiądz Michał wyjechał przed 23 marca 1938 roku, kiedy jego miejsce zajął Tymoteusz Mackiewicz. Nie znamy dalszej pracy duszpasterskiej księdza Bożerianowa. Wiadomo tylko, że nie miał stałej parafii. W 1939 roku współpracował z wydawanym w Wilnie „Dwutygodnikiem Prawosławnym”, o czym świadczy podziękowanie redakcji czasopisma za przesłane jej życzenia i artyku1 ${ }^{13}$. Z notki redakcyjnej wynika, że Bożerianow zamieszkiwał na terenie obsługiwanym przez pocztę w Kleszczelach. Prawdopodobnie wówczas przystąpił do organizacji monarchistów rosyjskich „Bractwo Ruskiej Prawdy”. Zapewne wiosną 1940 roku wraz z innymi

\footnotetext{
5 „Woskresnoje Cztienije”, nr 38, Warszawa 1937, s. 524

${ }^{6}$ Tamże, nr 20, s. 318.

${ }^{7}$ Archiwum Warszawskiej Metropolii Prawosławnej w Warszawie, Akta personalne księży, R IV6A, nr 1092, s. 48 .

${ }^{8}$ Tamże, s. 50-53.

9 „Woskresnoje Cztienije”, nr 22, Warszawa 1937, s. 272.

${ }^{10} \mathrm{~K}$. Urban, Z dziejów Kościoła prawosławnego na Łemkowszczyźnie, „Cerkowynyj Wiestnik”, R. XXXVIII, nr 8 (1991), s. 50.

11 „Woskresnoje Cztienije”, nr 40, Warszawa 1937, s. 642.

${ }^{12}$ Ks. G. Sosna, Katalog światyń $i$ duchowieństwa prawosławnej diecezji warszawsko-bielskiej,

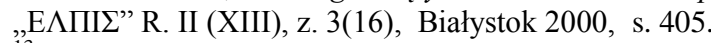

13 „Dwutygodnik Prawosławny. Organ Społeczno-religijny”, nr 3, Wilno 16-30 czerwca 1939 r., s. 12.
} 
duchownymi znalazł się na zesłaniu na terytorium azjatyckiej części Związku Radzieckiego. Nie znamy miejsca jego pobytu ani okoliczności jego zesłania. Z późniejszej notatki konsula polskiego w Nairobi wynika, że przebywał w obozie na północy Rosji wraz z innymi zesłańcami z Polski i był sympatykiem państwa polskiego ${ }^{14}$.

W broszurze Moja odpowiedź ,,ludziom małym” ks. Michał Bożerianow napisał „Po okupacji terenu Polski w roku 1939 zostaję aresztowany. Tak rozpoczynam nowy okres swego życia, okres więzień, badań, przesłuchiwań i wreszcie łagrów. Nie moją rzeczą jest pisać o sobie, o moim nastawieniu i pracy, szczególnie w okresie pobytu w łagrze. Mimo to, jestem więcej niż przekonany, że nie znajdzie się nikt spośród tych, którzy wspólnie ze mną ten okres przebyli, kto by mógł powiedzieć o mnie źle. Znając doskonale literacki język rosyjski byłem zatrudniony czasem w pracy umysłowej. Sumiennością w pracy zjednywałem sobie przełożonych i dzięki temu właśnie mogłem pomagać i pomagałem licznym Polakom. I znowu nie chcę uzasadnić tego swojego twierdzenia. Ale podnieść pragnę, że często w tym właśnie okresie doznawałem krzywd od pewnych byłych urzędników polskich. Ci to właśnie ludzie, chcąc zyskać sobie swoich przełożonych obozu, donosili na mnie o uprawianiu praktyk religijnych nie tylko dla siebie, ale także dla innych.

Zdaje się, że nie bez głębszego znaczenia jest fakt, iż w tym czasie u mnie, księdza prawosławnego, spowiadali się dwaj księżą rzymsko-katoliccy. Pobyt mój w łagrze zakończył się tym, że wraz z czterema moimi kolegami Polakami zostaliśmy wysłani karnie w celu postawienia nas pod sąd. I tylko dzięki wydanej wówczas amnestii uniknęliśmy epilogu tej sprawy"15.

Dzięki tejże amnestii duchowny w marcu 1942 roku wydostał się do miejscowości Pehlevi w Iranie. O tych wydarzeniach tak wspominał ks. Michał: „W marcu 1942 roku transportem ewakuowanym z Rosji przybyłem do Persji. W Pahlevi rozpoczynam pracę w szpitalu polskim. Gdy trzeba było być kapłanem, byłem nim, a równocześnie pełniłem funkcje sanitariusza, często nosząc nocniki i spełniając z pogodnym uczuciem cały szereg innych, tego rodzaju czynności. Uważałem to bowiem za bardziej niż ludzkie (...)"16. W raz z nimi w marcu i sierpniu 1942 r. do Iranu ewakuowano 37912 osoby cywilne różnych narodowości i wyznań. Wśród nich znajdowali się również liczni obywatele polscy narodowości białoruskiej. Strona sowiecka na różne sposoby utrudniała ewakuację nie - Polaków (głównie Białorusinów i Ukraińców). Ażby wydostać się z granic ZSRR, obywatele polscy narodowości białoruskiej podawali się za Polaków, niekiedy zmieniając imiona i nazwiska.

W Iranie ksiądz Michał Bożerianow objął opiekę duszpasterską nad przebywającymi tam prawosławnymi cywilami. „W roku tym święta wielkanocne prawosławnych i rzymsko-katolików wypadały równocześnie. W Pehlevi była niewielka cerkiew prawosławna, w której odprawiałem nabożeństwa w Wielkim Tygodniu i na Wielkanoc. Zapoznałem się z liczną kolonią prawosławną. Namówiłem wielu z tej kolonii, aby odwiedzili obóz uchodźców polskich w Pehlevi i w miarę możliwości podzielili się z nimi „święconym”. W drugim i w trzecim dniu świąt udaliśmy się na teren obozu polskiego, gdzie miejscowi prawosławni rozdawali wśród uchodźców bez różnicy wyznania

\footnotetext{
${ }^{14}$ J. Grzybowski, Białorusini $w$ polskich regularnych formacjach wojskowych $w$ latach 1918-1945, s. 284, 369, przyp. 529.

${ }^{15}$ M. Bożerianow, Moja odpowiedź ,,ludziom małym”, Tengeru, Arusha, Tanganyika 1945, s. 11.

${ }^{16}$ Tamże, s. 12.
} 
okolicznościowe dary. W ten sposób pewna część ludności po długiej przerwie mogła spożywać normalne święcone, składające się z wędlin, ciast, cukrów i słodyczy"17.

Po krótkim pobycie w Pehlevi ks. M. Bożerianow udał się do Teheranu. W Teheranie ksiądz Michał Bożerianow zorganizował obozową kaplicę, w której regularnie odprawiane były nabożeństwa prawosławne. W marcu 1942 r. w Teheranie rozpoczął działalność Polski Prawosławny Kościół Autokefaliczny. Prawosławny ośrodek został zorganizowany w Obozie Uchodźców Polskich (OUP) nr 2, gdzie zbudowano kaplicę. Kaplicę prawosławną w OUP nr 1 wybudowano w kwietniu 1943 r. Druga fala ewakuacyjna w sierpniu 1942 r. powiększyła liczbę prawosławnych o kolejnych 1500 osób, w tym dwóch księży: Wsiewołoda Jaskowa i Włodzimierza Pietruczyka. W październiku 1942 r. na terenie obozów w Teheranie przeprowadzono spis uchodźców polskich, z którego wynika, że w OUP nr 1 znajdowało się 370 osób wyznania prawosławnego, w OUP nr $2-450$, w OUP nr 3 - 540, w szpitalach - 130, natomiast w mieście mieszkało dodatkowo 160 osób. Ogólną liczbę prawosławnych ustalono na 1650, jednak znaczna część Białorusinów nadal ukrywała swoje wyznanie i podawała się za Polaków-katolików ${ }^{18}$.

Rozumiejąc sytuację znajdującej się tam ludności prawosławnej, przy poparciu polskiej misji wojskowej, ksiądz Michał Bożerianow wydał w Teheranie w 1942 roku „Prawosławny Modlitewnik”. Od listopada 1942 do lutego 1943 r. ks. Bożerianow przy materialnej pomocy Ministerstwa Pracy i Opieki Społecznej, wydał 1000 egzemplarzy zbioru modlitw prawosławnych. Duchowny zorganizował również redakcję, która zaczęła wydawać w styczniu 1943 r. miesięcznik „Ziarenko prawosławne”, adresowane do prawosławnych cywili i wojskowych. Autor broszury Moja odpowiedź ,ludziom małym” o tych faktach wspominał: „Opuściwszy Pahlevi, przybyłem do Teheranu, gdzie istniało wiele obozów dla ewakuowanej ludności cywilnej. Zorganizowałem życie religijne w obozach oraz parafię prawosławną. Lojalnie podkreślić muszę, jak wiele w tym wysiłku zawdzięczam osobistym walorom p. Wiktora Styburskiego, ówczesnego Delegata w

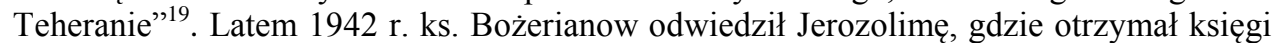
liturgiczne i nawiązał kontakt z duchowieństwem prawosławnym. Dzięki swej pracy duszpasterskiej ks. Bożerianow zyskał ogromny autorytet i szacunek wśród uchodźców narodowości białoruskiej.

Wiadomości o działalności duszpasterskiej i wydawniczej duchownego Bożerianowa dotarły do biskupa Sawy Sowietowa. W 1942 roku władyka Sawa został mianowany zwierzchnikiem duszpasterstwa prawosławnego w Wojsku Polskim ${ }^{20}$. Ks. M. Bożerianow

\footnotetext{
${ }^{17}$ M. Bożerianow, Moja odpowiedź ,,ludziom matym”, s. 12.

${ }^{18}$ J. Grzybowski, Białorusini w polskich regularnych formacjach wojskowych w latach 1918-1945, s. 368.

${ }^{19}$ M. Bożerianow, Moja odpowiedź ,ludziom matym”, s. 12. Pobyt tak dużej liczby Polaków w Iranie wymagał działań na szczeblu dyplomatycznym. 3 kwietnia 1942 r. w Teheranie utworzono Delegaturę Ministerstwa Pracy i Opieki Społecznej Rządu Polskiego. Jej kierownikiem został Wiktor Styburski, późniejszy naczelnik Wydziału Służby Zdrowia przy Delegaturze Ministerstwa Pracy i Opieki Społecznej w Bombaju.

${ }^{20}$ O działalności duszpasterskiej i politycznej biskupa Sawy w Wojsku Polskim na emigracji por. Arcybiskup general brygady Sawa (Jerzy Sowietow). Wybór dokumentów, opr. K. Filipow, i A. Suchcitz, Białystok-Warszawa 1997; A. Zięba, „,Wojna popów”. Polskie prawosławie na emigracji po II wojnie światowej, „Zeszyty Naukowe Wydziału Historycznego Uniwersytetu Jagiellońskiego”, Kraków 1998, s. 31-51.
} 
cieszył się pełnym zaufaniem władyki grodzieńskiego. Biskup Sawa w posłaniu z 23 lutego 1943 roku z Nowego Jorku do polskich żołnierzy prawosławnych napisał: „Ucieszyłem się ogromnie, gdy od gorliwego duszpasterza X. Bożerianowa z Teheranu otrzymałem wiadomość o Waszym ocaleniu, o Waszej pracy nad utrzymaniem i pogłębieniem życia religijnego. Boski nasz Zbawiciel, który sam w młodości swej musiał opuścić umiłowaną Ojczyznę i był na tułaczce w Egipcie, czuwał nad Wami”"21. W innym miejscu posłania biskup Sawa nawiązuje do działalności wydawniczej księdza Michała. „Z prawdziwym wzruszeniem przyjąłem dar najmilszy „Prawosławny Modlitewnik” wydany w Teheranie. Bóg Wam serdecznie zapłać za Wasze modły na moją intencję. Dodają mi one sił do pracy dla dobra naszego świętego Kościoła i Ojczyzny Polski. Módlcie się często na intencję naszej Rzeczypospolitej, Jej Prezydenta, Jej Naczelnego Wodza i wszystkich przełożonych, na barkach których spoczywa ogromny nawał wszelkich prac. Razem z Wami modlę się powtarzając słowa z Modlitewnika: „Wojsku naszemu daj zwycięstwo nad wrogami, Rządzącym włóż do serc dobre, mądre i sprawiedliwe dążenia. Umysły ich wzmocnij i siły pokrzep". Błogosławię waszemu czasopismu „Ziarnko Prawosławne”, jego redaktorom, czytelnikom i opiekunom. Niech ziarno zasiane wyda plon ewangeliczny"22. Analizując korespondencję biskupa Sawy należy zauważyć, że władyka miał pełne informacje o działalności księdza Bożerianowa. Obydwaj duchowni dobrze znali się przed wybuchem wojny, a w czasie pobytu ojca Michała w Teheranie utrzymywany był między nimi stały kontakt korespondencyjny.

W sprawie posłania biskupa Sawy i jego zainteresowań działalnością księdza Bożerianowa pisał w tajnym raporcie profesor Klemens Jędrzejewski 26 lutego 1943 roku do rządu polskiego w Londynie. „Załączam kilka egzemplarzy tekstu pasterskiego listu Sawy do prawosławnych na Wschodzie. Biskup prosi o wysłanie jednego egzemplarza do ks. Michała Bożerianowa, proboszcza prawosławnych polskich obozów cywilnych w Teheranie. X. Bożerianow nadesłał Sawie szereg listów z raportami i prośbą o naczynia liturgiczne. Biskup jest przekonany, że te potrzeby zostały zaspokojone przez nasze placówki albo w Jerozolimie albo w Konstantynopolu. Sawa prosi o spis prawosławnych duchownych, którzy tam jeszcze są. Prosi również o maximum informacji o prawosławnych na Wschodzie oraz o aktywność Rządu Polskiego na tym odcinku. Wiadomości te są niezmiernie ważne dla pozytywnej pro-polskiej działalności biskupa na tutejszym terenie. (...) Najważniejszą jednak sprawą, na co raz jeszcze pozwalam sobie zwrócić uwagę, jest nawiązanie kontaktu między biskupem Sawą a duchowieństwem prawosławnym na Wschodzie. Pożądane są fotografie z życia prawosławnych uchodźców, numery czasopism „Ziarenko Prawosławne” (Teheran), lista duchownych”23. Z listu tego wynika, że ksiądz Michał Bożerianow pozostawał jeszcze w lutym 1943 roku w Teheranie i prowadził nadal działalność wydawniczą.

Wśród uchodźców polskich narodowości białoruskiej brakowało inteligencji i może dlatego dopiero w połowie 1942 r. powstał ruch narodowy na czele z ks. Michałem Bożerianowem. W Teheranie ks. Bożerianow powołał do życia Komitet Białoruski, na którego czele sam stanął. Komitet wydał wiele odezw do rządu polskiego i amerykańskiego, w których negatywnie ocenił włączenie województw wschodnich II Rzeczypospolitej do ZSRR. Ks. M. Bożerianow pragnął wprowadzić przedstawiciela

\footnotetext{
${ }^{21}$ Arcybiskup generał brygady Sawa (Jerzy Sowietow), Aneks 1. (bez numeru stron).

22 Tamże.

${ }^{23}$ Arcybiskup generat brygady Sawa (Jerzy Sowietow), Aneks 2.
} 
mniejszości białoruskiej do polskiej Rady Narodowej na obczyźnie. O motywach innej inicjatywy pisał sam ks. M. Bożerianow. „Ciężkie były to chwile dla spraw Rzeczypospolitej Polskiej. I dlatego chwila ta wymagała wyjątkowego zrozumienia i jak najlepszej woli wszystkich Jej obywateli bez różnic narodowościowych i wyznaniowych. Niestety większa część owego społeczeństwa polskiego w Teheranie nie chciała, czy też nie umiała zrozumieć tej potrzeby. Swoją dziecinną wprost gadatliwością i pompatycznym hurra-patriotyzmem, często mimo woli wbijali liczne gwoździe do przygotowanej trumny dla polskiej państwowości. Miast jedności i pracy twórczej społeczeństwo to rozpoczęło wskrzeszać, zdawałoby się raz na zawsze pogrzebaną przeszłość przedwrześniową. I znów niechęć do mniejszości narodowych i wyznaniowych, aczkolwiek też obywateli polskich, poczęła święcić swoje triumfy. Wielu z nich systematycznie i celowo starało się problem ten zaogniać. I nic też dziwnego, że niechęć ta przeradzać się poczęła w otwartą nienawiść. Tak to, większość społeczeństwa polskiego na uchodźctwie, zdążać zaczęła szerokim szlakiem do przepaści.

Mimo to doskonale doceniałem całą powagę tej chwili. Postanowiłem działać. Po porozumieniu z przyjaciółmi, zabrałem się do pracy. Przede wszystkim zwróciłem się do uchodźców prawosławnych z kategorycznym wezwaniem, by nie zważali na idiotyczną politykę niektórych spośród większości, i by nie dali się sprowokować do żadnych reakcji, lecz wysiłkiem dobrej woli poparli politykę ówczesnego Premiera Rządu i Naczelnego Wodza ś.p. Generała Broni Władysława Sikorskiego, największego ówczesnego męża stanu Polski. Parafianie zrozumieli doskonale moje intencje i mimo wszystko postanowili przyjść z pomocą sprawie Polski, nie zwracając żadnej uwagi na docinki hałasujących „niemowląt polityczno-państwowych”.

O tym postanowieniu ludności prawosławnej powiadomić chciałem Generała Sikorskiego. Ułożyłem odpowiednią deklarację, zebrałem podpisy prawosławnych i deklarację tę wysłałem. Niestety, nawet tego rodzaju stanowisko prawosławnych spotkało się z niezrozumiałym dla mnie oburzeniem, oszołomionego nagłą wolnością społeczeństwa polskiego. Lojalnie przyznać muszę, iż pewien odsetek społeczeństwa polskiego zajął przychylne stanowisko. Większość jednak bezkrytycznie potępiła fakt deklaracji. Cui bono?"24.

W rzeczywistości sprawa wyglądała nieco inaczej. Ze względu na swoje polonofilskie nastawienie ks. Michał Bożerianow stał się obiektem zainteresowania niektórych polskich polityków o poglądach federalistycznych, przebywających wówczas w Iranie. W 1942 r. nawiązał z nim kontakt członek Rady Narodowej mgr Franciszek Wilk i zaproponował podjęcie współpracy w sprawie walki Polski o Kresy Wschodnie. W rezultacie Wilk namówił ks. Bożerianowa do powołania wśród obywateli polskich wyznania prawosławnego Komitetu Białoruskiego. Celem tego Komitetu była działalność polityczna w imieniu narodu białoruskiego i podniesienie kwestii białoruskiej do poziomu międzynarodowego. Prezesem Komitetu Białoruskiego został ks. Bożerianow. Oprócz niego w skład Komitetu weszli m. in. Ludmiła Szewczuk, Włodzimierz Tomasz, Jan Bodgusiejew, Filip Huryn i inni. 23 września 1942 r. w Teheranie Komitet Białoruski wydał swój pierwszy memoriał do premiera rządu polskiego i Naczelnego Wodza gen. Władysława Sikorskiego. W imieniu wszystkich warstw (inteligencji, chłopów, młodzieży) obywateli polskich narodowości białoruskiej podpisy złożyło 61 osób, w tym 3 Ukraińców. W memoriale Białorusini dali wyraz swojej przychylności dla państwa

${ }^{24}$ M. Bożerianow, Moja odpowiedź ,,ludziom matym”, s. 12. Cui bono? - Kto korzysta? 
polskiego. Czytamy w nim m.in.: ,jakkolwiek tylko garstka nas mogła dostać się dzięki Ambasadzie RP w Rosji i Dowództwu Armii w ZSRR na ziemię irańską, to jednak, znając doskonale uczucia i dążenia tysięcy naszych współrodaków, których głos nie może być usłyszany przez świat, gdyż odpłaciliby to nowym więzieniem, składamy deklarację i podpisujemy ją również w imieniu tych wszystkich, którzy w granicach ZSRR jeszcze się znajdują. My, Białorusini, jesteśmy historycznie związani z Polską, z jej losami, jak również i Jej rozwojem od czasów unii litewskich ziem z Polską (...). Od tego czasu powodzenie i szczęście Polski było naszym szczęściem, niepowodzenia Polski - naszym nieszczęściem (...).",25.

W memoriale, przytaczając historyczne przykłady udziału Białorusinów w obronie granic Rzeczypospolitej, działacze Komitetu Białoruskiego wyrażali gotowość dalszej walki o niepodległość Polski, jak to robili ich ojcowie książęta Ostrogscy i Wiśniowieccy w XVI wieku. W memoriale obywatele polscy narodowości białoruskiej wyrażali protest przeciwko agresji sowieckiej na Polskę w 1939 r., kwestionowali dobrowolne przyłączenie Zachodniej Białorusi do Związku Sowieckiego, zaznaczając, że wolą Białorusinów zawsze było przynależność do Polski, a nie do Rosji. W memoriale zaznaczono: „Celem naszym jest nie Rosja, nie Niemcy, lecz Polska. Do Polski chcemy należeć. Rząd Polski jest naszym Rządem”. Komitet Białoruski oskarżał również Niemcy o pacyfikację i gnębienie ziem białoruskich, zniszczenie duchowieństwa i kultury narodowej. W zakończeniu memoriału Białorusini składali podziękowanie gen. Władysławowi Sikorskiemu, ambasadorowi Stanisławowi Kotowi oraz gen. Władysławowi Andersowi za możliwość wydostania się z niewoli sowieckiej: „Z całego serca dziękujemy Panu Ambasadorowi RP prof. Stanisławowi Kotowi za jego gorliwą opiekę i pomoc udzieloną na terenie Rosji. Wdzięczność nasza dla Niego jest tym większa, że wiemy jakie trudności czynił Rząd Sowiecki, by nie wypuścić ani jednego Białorusina poza granice ZSRR. Wysiłek pana Ambasadora Stanisława Kota i Dowódcy Polskich Sił Zbrojnych w ZSRR Pana Generała Andersa sprawił, że jesteśmy dziś na gościnnej ziemi perskiej, jako wolni obywatele polscy. I im za to serdeczne Bóg zapłać" ${ }^{26}$.

Rzeczywiście ks. Michał Bożerianow w imieniu ludności prawosławnej wysłał deklarację lojalności wobec rządu RP w Londynie 23 września 1942 r. Adresat otrzymał deklarację albowiem 23 listopada poseł nadzwyczajny i minister pełnomocny Rzeczypospolitej Polskiej w Teheranie Karol Bader odpisał duchownemu: „Wielebny Ojcze, będąc dokładnie poinformowanym o działalności Wielebnego Księdza i dowodach głębokiego przywiązania do Rzeczypospolitej Polskiej, niezmiernie jest mi miło przesłać na ręce Pańskie, podziękowanie Pana Premiera Rządu RP Generała Władysława Sikorskiego dla Białorusinów, za deklarację przesłaną Panu Premierowi w dniu 23 września 1942 r. „Przywiązanie swoje do Polski Białorusini udowodnili czynem nie po raz pierwszy w historii, we wrześniu 1939 roku. Od tego czasu wspólne cierpienia i wspólne walki wzmocniły więzy, łączące nas. Jedność uczuć i celów staną się niezachwialnym fundamentem, na którym odbudujemy wspólnym wysiłkiem Polskę

\footnotetext{
${ }^{25}$ J. Grzybowski, Białorusini w polskich regularnych formacjach wojskowych $w$ latach 1918-1945, s. $370-371$.

${ }^{26}$ M. Dymarski, Białorusini z armia gen. Andersa. Przyczynek do dziejów ludności Kresów Wschodnich, [w:] Tematy polsko-białoruskie. Historia - literatura - edukacja, Olsztyn 2003, s. 151161 .
} 
wolną i sprawiedliwą dla wszystkich Jej synów". Łączę wyrazy prawdziwego szacunku /-/ K. Bader, Poseł R.P., 27 .

11 listopada 1942 r. Minister Obrony Narodowej gen. Marian Kukiel wysłał za pośrednictwem Dowództwa Armii Polskiej na Wschodzie oficjalną odpowiedź na memoriał Białorusinów. Czytamy w niej m.in.: „Proszę przyjąć do wiadomości, że tak Naczelny Wódz i Premier, jak i ja, pamiętamy o wszystkich obywatelach i staraliśmy się i staramy przynieść ulgę obecnie cierpiącym, a na przyszłość wywalczyć dla wszystkich obywateli Państwa lepszą i jasną przyszłość, jak również proszę pamiętać, że wszystkie cierpienia i krzywdy, jakie nawiedziły Białoruś od września 1939 r., są znane i dokładnie notowane. Jako minister obrony narodowej i członek rządu, wzywam Was, Białorusinów, jak wszystkich obywateli Polski, do najbardziej intensywnej pracy i przygotowania się do walki z największym wrogiem - Niemcami. Tylko praca i walka może dać nam wszystkim wolność i powrót do oswobodzonej Ojczyzny"28.

W liście do Dowództwa Armii Polskiej na Wschodzie z 10 grudnia 1942 r. gen. Kukiel polecał popierać akcję ks. Bożerianowa i mgr Wilka oraz udzielać im potrzebnej pomocy. Reakcja była natychmiastowa. Szef sztabu Armii Polskiej na Wschodzie generał Bronisław Rakowski (1887-1957) napisał już 24 grudnia 1942 r. do ks. M. Bożerianowa ${ }^{29}$. „Pan Minister Obrony Narodowej R.P. w Londynie polecił przekazać Księdzu Proboszczowi następującą depeszę: „,W imieniu Naczelnego Wodza i moim dziękuję za to pismo i zapewniam, że zgadzam się całkowicie z podpisami, a sądzę, że i nie podpisami, że Państwo Polskie jest całe i nierozłączone dla wszystkich obywateli, bez względu na język i religię. Proszę przyjąć do wiadomości, że tak Naczelny Wódz i Premier, jak i ja pamiętamy o wszystkich obywatelach i staraliśmy się i staramy przynieść ulgę obecnie cierpiącym, a na przyszłość wywalczyć dla wszystkich obywateli Państwa lepszą i jaśniejszą przyszłość. Jako Minister Obrony Narodowej i członek Rządu wzywam do najbardziej intensywnej pracy i przygotowania się do walki z największym wrogiem wszystkich ludów - Niemcami. Tylko wspólna praca i walka może dać nam wszystkim wolność i powrót do wyswobodzonej Ojczyzny". Szef Sztabu Armii Polskiej na Wschodzie /-/ Rakowski, Generał Brygady" ${ }^{\prime 30}$.

Oficjalna reakcja rządu polskiego na memoriał nastąpiła dopiero 16 stycznia 1943 r., kiedy większość Białorusinów przygotowywało się do wyjazdu do Afryki Wschodniej. Stanisław Mikołajczyk (1901-1966) ${ }^{31}$ skierował wówczas list do Konsulatu Generalnego RP w Nairobi z prośbą o przekazanie podziękowań dla wiernych Rzeczypospolitej obywateli polskich narodowości białoruskiej. W liście m.in. zapisał: „Odpowiadając na deklarację obywateli polskich białoruskiej narodowości przesłaną Panu Premierowi dla Rządu Rzeczypospolitej proszę złożyć na ręce księdza Michała Bożerianowa podziękowanie wiernym Rzeczypospolitej Białorusinom i zapewnienie, że w

\footnotetext{
${ }^{27}$ M. Bożerianow, Moja odpowiedź , ludziom małym”, s. 14. Karol Bader (1887-1957) był posłem nadzwyczajnym RP w Teheranie od 1 lipca 1942 do 30 czerwca 1945.

${ }^{28}$ Cyt. za: J. Grzybowski, Białorusini $w$ polskich regularnych formacjach wojskowych $w$ latach 1918-1945, s. 371-372.

${ }^{29}$ Bronisław Rakowski od września 1942 do sierpnia 1943 był szefem sztabu Armii Polskiej na Wschodzie a następnie do stycznia 1945 dowódcą 2 Brygady Pancernej.

${ }^{30} \mathrm{M}$. Bożerianow, Moja odpowiedź ,ludziom malym”, s. 14.

${ }^{31}$ Stanisław Mikołajczyk, wicepremier (1940-1943), a od lipca 1943 (po śmierci gen. Władysława Sikorskiego) do listopada 1944 r. premier rządu RP na uchodźstwie.
} 
odbudowanej Rzeczypospolitej obywatelom polskim narodowości białoruskiej zagwarantowane będą prawa zupełnej równości obywatelskiej, zabezpieczone warunki swobodnego rozwoju kulturalno-narodowego, oraz uwzględnienie interesów społecznogospodarczych najszerszych warstw białoruskiego ludu pracującego (...)"32.

Raz jeszcze minister Stanisław Mikołajczyk wysłał 2 marca 1943 r. w tej sprawie depeszę do pełnomocnego posła Karola Bader dowiedziawszy się, że ks. Bożerianow pozostaje nadal w Teheranie. Poseł o treści depeszy informował duchownego prawosławnego. „Pan Minister Mikołajczyk polecił mi złożyć na ręce Wielebnego Księdza (...) podziękowanie wiernym Rzeczypospolitej Białorusinom oraz zapewnić ich, że W odbudowanej Polsce obywatelom polskim, narodowości białoruskiej będą zagwarantowane prawa zupełnej równości obywatelskiej oraz zabezpieczone warunki swobodnego rozwoju kulturalno-narodowego, jak i uwzględnione interesy politycznogospodarcze najszerszych warstw pracującego ludu białoruskiego. /-/ K. Bader, Poseł R.P.",33

Zupełnie odmienne stanowisko zajęli wobec inicjatywy duchownego prawosławnego uchodźcy polscy narodowości polskiej, przebywający na terenie Iranu. Najlepiej ową postawę uchodźców polskich w Iranie wobec mniejszości po wysłaniu ich deklaracji do rządu RP w Londynie zaprezentował sam ks. M. Bożerianów we wspomnianej już broszurze. „Rozpoczęto kampanię przeciwko mnie, do czego już »z tradycji« zdołałem się przyzwyczaić. Symptomatycznie patrzeć poczęto na mnie »popa prawosławnego«. Tego rodzaju stanowisko trzeba było za wszelką cenę uzasadnić faktami. Trzeba było za wszelką cenę udowodnić mi ınnieprawomyślność«. Toteż Straż Bezpieczeństwa i żandarmeria wojskowa zaczęły mnie inwigilować. Nie mogąc znaleźć nic konkretnego, chwycili się zwykłej prowokacji. Poczęli rozpowszechniać pogłoski, iż jestem wrogiem narodu polskiego, że prowadzę robotę antypaństwową. Ba, co więcej, uznali, że wszyscy moi współpracownicy, jako też Polacy utrzymujący ze mną stosunki towarzyskie - są wrogami Polski. Walka zaczęła się toczyć zupełnie otwarcie. Panu mgr. Franciszkowi Wilkowi, ówczesnemu członkowi Rady Narodowej w Londynie ${ }^{34}$, żandarmeria oświadczyła otwarcie ,musimy zlikwidować ks. Bożerianowa, ale nie możemy go uchwycić".

Tego rodzaju nastawienie do mnie zwiększyło proporcjonalnie atawistyczną niechęć większości do wszystkich prawosławnych. Toteż nic dziwnego, że zupełnie otwarcie padały zdania, że »mniejszości trzeba powystrzelać«. Nie oszczędzano naszego życia religijnego. W pobliżu kaplicy prawosławnej w obozie nr 3 rozchodząca się z nabożeństw ludność prawosławna często słyszała zdania, że » ten sklepik (tzn. kaplicę prawosławną) i jej robotników (tzn. mnie i wiernych) prędko zlikwidujemy«. Miarą tego rodzaju ustosunkowania się większości dopełniał fakt, że reprezentującymi tego rodzaju zbożne życzenia, byli także różni oficjalni przedstawiciele. Straż Bezpieczeństwa, a więc strażnicy ładu i porządku, czyniła to samo. Tego rodzaju działalność znajdywała poparcie nawet u ,góry".

\footnotetext{
${ }^{32}$ Cyt. za: J. Grzybowski, Białorusini $w$ polskich regularnych formacjach wojskowych $w$ latach 1918-1945, s. 372.

${ }^{33}$ M. Bożerianow, Moja odpowiedź ,,ludziom matym”, s. 15.

${ }^{34}$ Franciszek Wilk, członek Rady Narodowej w Londynie.
} 
Pewnego razu przybył na wizytację obozu zastępca Delegata M. P. i O. Sp. p. Pająk ${ }^{35}$. Zwrócił się do jednej urzędniczki, mojej znajomej, z oświadczeniem: »co prawda pani czyni to, co sama uważa, ale pani jest urzędniczką (...) jest pani na posadzie (...) niech lepiej pani zaprzestanie chodzić do duszpasterstwa prawosławnego«, dodając »pani jest urzędniczką, nie wypada aby pani tam chodziła«. Sapienti sat ${ }^{36}$.

W tych warunkach stosunek większości personelu zatrudnionego w obozach stawał się coraz bardziej nieprzychylny do prawosławnych. Rozpoczęto rugowanie pracowników fizycznych wyznania prawosławnego. Jaskrawym dowodem tego niech będzie fakt zwolnienia prawosławnego Ignacego Guryna, któremu przełożony bez żadnych ogródek oświadczył » po co nam prawosławni? «.

W celu podwyższenia mego autorytetu kapłana wśród wiernych prawosławnych rozpowszechniano plotkę, że w moim mieszkaniu odbywają się orgie itp., a jako uczestników tychże podano nazwiska osób, które pomagając mi w pracy bywali u mnie. Dziwna rzecz, iż nie odważono się podać nazwisk licznych Polaków i Polek, które bardzo często byli moimi gośćmi, często przebywając u mnie do późnych godzin wieczornych.

Tego rodzaju nagonkę i oszczerczą kampanię wszczęła przeciwko mnie i prawosławnych większość uchodźctwa polskiego w nierozumnej nienawiści za moje stanowisko do ówczesnego Rządu Polskiego, w ogólności, a za wysłanie wspomnianej deklaracji w szczególności. Toteż nic dziwnego, że wiadomość o nadesłaniu dla mnie i prawosławnych podziękowania od śp. Generała Sikorskiego za treść deklaracji, o której miał On się wyrazić, iż jest ona jednym z ważniejszych dla Polski dokumentów, doby obecnej, - powiększyła jeszcze wrogie nastawienie do mnie ze strony tych » niemowląt polityczno-państwowych«.

W tym samym czasie, gdy rozpaleni do białej gorączki szowiniści polscy starali się przy pomocy całego arsenału podłych insynuacji oczerniać mnie i moich ludzi, gdy zupełnie jawnie ogłaszali nas za wywrotowców - czynniki rządowe przysyłały na moje ręce podziękowania. Chyba jest to wystarczającym dowodem, stwierdzającym jak większość uchodźctw pojmowała istotę interesów państwowych, wyrządzając często Rządowi Rzeczypospolitej Polskiej więcej zła, niźli okazując obywatelskiego zrozumienia.

Może kiedyś obiektywna historia oceni szkody wyrządzone Polsce przez samą emigracje i uchodźctwo polskie, którzy w swym ograniczeniu umysłowym nie potrafili dojrzeć prawdziwej drogi wypełnienia swych obowiązków. Tak do rzędu zewnętrznych wrogów Polski dochodzili gorsi, bo właśni. O » wrogiej mojej działalności najlepiej zorientować się może czytelnik, z niżej podanych pism «"37. Tam następowały pisma nadesłane na ręce duchownego prawosławnego ze strony najwyższych przedstawicieli rządu polskiego w Londynie.

Mimo przychylnej postawy polskiego rządu wobec działalności Komitetu Białoruskiego, działalność ks. Bożerianowa napotykała na liczne przeszkody ze strony niektórych czynników wojskowych. Jak wynika z notatki mgr Wilka: „W drodze do miasta jeden żandarm opowiadał mi, że chcą zlikwidować księdza Bożerianowa i jego

\footnotetext{
35 Antoni Pająk, działacz PPS (1893-1965). Od września 1943 r. do lipca 1945 był delegatem Ministerstwa Pracy i Opieki Społecznej Rządu RP na uchodźctwie przy Armii Polskiej na Wschodzie.

${ }^{36}$ „Sapenti sat” - wystarczająco mądre.

${ }^{37}$ M. Bożerianow, Moja odpowiedź ,ludziom malym”, s. 13-14.
} 
robotę, tylko nie mogą sobie z nim dać rady. Oświadczyłem, że przez taki stosunek do księdza Bożerianowa wyrządzą największą szkodę sprawie polskiej, ponieważ ksiądz Bożerianow przeprowadził $\mathrm{w}$ obozie wśród Białorusinów deklarację na ten temat. Popatrzył na mnie $\mathrm{z}$ niedowierzaniem, wobec tego dałem mu do przeczytania tę deklarację. Przyznał, że to dobre osiągnięcie”. O tym wydarzeniu mgr Wilk poinformował Ministerstwo Spraw Wojskowych jeszcze w październiku $1942 \mathrm{r}^{38}$

Nie zwracając uwagi na prowokacje polskich służb specjalnych Komitet Białoruski pod kierownictwem ks. Bożerianowa 25 marca $1943 \mathrm{r}$. wysłał memoriał do prezydenta Stanów Zjednoczonych Ameryki Franklina D. Roosevelta. W wysłanym memoriale jego autorzy napisali: „W imieniu Narodu Białoruskiego, tj. inteligencji białoruskiej, chłopów i robotników, obywateli polskich, pochodzących z ziem północnych i wschodnich Rzeczypospolitej Polskiej - Komitet Białoruski zwraca się do waszej Excelencji z gorącą prośbą wysłuchać naszego głosu całego Narodu Białoruskiego z ziem polskich, zechcieć zrozumieć tragedię naszą Białorusinów, wstawić się za nami i pomóc nam urzeczywistnić nasze pragnienia. Podkreślamy, że Komitet Białoruski odzwierciedla uczucia i dążenia milionów naszych współrodaków, których głos i wola nie mogą być dziś usłyszane przez Świat”. Jednym z celów memoriału było wyrażenie kategorycznego protestu przeciwko przyłączeniu Kresów Wschodnich do ZSRR. W związku z tym obywatele polscy narodowości białoruskiej pisali: „Rosja Sowiecka oficjalnie oznajmiła światu, iż wschodnie Ziemie Polskie, zamieszkałe przez nas, Białorusinów, uważa za swoje i chce po zakończeniu wojny wcielić je w granice swego państwa. Wobec społeczeństw całego świata kategorycznie protestujemy przeciw oderwaniu nas od Polski. Nigdy nie zgodzimy się na przynależenie do Rosji! Wolą Narodu Białoruskiego jest, by nasze życie, nasze losy, nasze rodziny, gospodarstwa, ziemia - należały do Polski i były związane z Nią i jej losem. Tylko z Polską współżyjąc i współpracując będziemy spokojni o swój los i będziemy mogli dojść do dobrobytu i szczęścia jak też i do pełnego rozwoju kultury narodowej”39. Jako argument na rzecz przyłączenia Białorusi Zachodniej do państwa polskiego Komitet Białoruski wysunął wielusetletnią wspólną walkę Polaków i Białorusinów przeciwko agresji ze Wschodu. W memoriale Traktat Ryski został potraktowany przez Komitet jako zjawisko negatywne dla ludności białoruskiej. W memoriale Białorusini twierdzili, że przyłączenie do Związku Sowieckiego wschodnich ziem Polski, zamieszkanych przez ludność białoruską, nastąpiło wbrew woli samych Białorusinów.

Komitet Białoruski skierował memoriał do aliantów w imieniu wszystkich Białorusinów, nawet tych, którzy zamieszkali na Białorusi Wschodniej i nigdy nie byli obywatelami Polski. Działacze Komitetu zwracali się do aliantów z prośbą o udzielenie pomocy w odzyskaniu niepodległości przez Polskę w jej przedwojennych granicach. Autorom memoriału nie był obojętny los swych rodaków przebywający na terenie ZSRR. „Usilnie prosimy Naród Amerykański wstawić się za nami i upomnieć się o nas u Rządu Sowieckiego, by zwolnił z więzień i przymusowych robót wszystkich współwyznawców współrodaków Białorusinów (obywateli polskich) i otworzył im granice swego państwa dla wyjazdu $\mathrm{z}$ Rosji. Równocześnie kategorycznie żądamy zwolnienia naszych współbraci z Czerwonej Armii i wojskowych batalionów pracy, umożliwiając im

\footnotetext{
${ }^{38}$ J. Grzybowski, Białorusini w polskich regularnych formacjach wojskowych w latach 1918-1945, s. 372.

${ }^{39}$ Tamże, s. 373-374.
} 
wstąpienie do szeregów Armii Polskiej. Zdajemy sobie sprawę, iż jesteśmy narodem bardzo odstającym od narodów o wysokiej cywilizacji, lecz to nie powinno być powodem by nasza wola nie została wzięta pod uwagę, gdy chodzi o nasz los. Ongiś w 1683 roku za króla polskiego Jana Sobieskiego pod Wiedniem wspólnie z Polakami nasi ojcowie Białorusini przelewali krew, broniąc Europy i Jej kultury: dziś my, ich dzieci, zwracamy się z apelem do miłującego cywilizację i wolność Wielkiego Narodu Amerykańskiego, by obronił nas przed zaborczością Rosji i dał nam możność należeć do Polskiej Rodziny, która od wieków jest naszą rodziną. Wierzymy w sprawiedliwość Narodów Demokratycznych, opartą o Kartę Atlantycką, i prosimy nie zapomnieć o nas przy stole pokojowym" "40. Prośba grupy lojalnych wobec Polski Białorusinów nie mogła wzbudzić zainteresowania aliantów. Władzom Stanów Zjednoczonych ważniejsze były dobre relacje ze swym strategicznym sojusznikiem Związkiem Radzieckim aniżeli prośby białoruskich uchodźców.

Wielkim ciosem dla propolsko nastawionej grupy białoruskiej będącej na uchodźstwie była śmierć gen. Władysława Sikorski w lipcu 1943 r. Władyka Sawa w liście do patriarchy konstantynopolitańskiego Beniamina z 30 lipca 1943 roku napisał: „Opłakuję z wielką żałością tragiczną śmierć śp. generała Sikorskiego (...). Za każdym razem, ilekroć przyjeżdżał do Ameryki zawsze zaszczycał mnie rozmową. Okazywał wielkie zainteresowanie dla prawosławnych, a w szczególności dla kapłanów i żołnierzy, oraz podkreślał ich oddanie Polsce". Mniej entuzjastycznie biskup pisał o następcy Sikorskiego, generale Kazimierzu Sosnkowskim, oczekując jedynie, że „nie zapomni o potrzebach naszych prawosławnych". W liście tym władyka Sawa wspomina o sytuacji prawosławnych duchownych na Wschodzie. „Otrzymałem od niektórych kapłanów listy świadczące, że pracują z poświęceniem, że zredagowali książkę do nabożeństwa, że ogłaszają nawet prawosławne ulotki periodyczne. To, czego im brakuje, to aparatów liturgicznych, w gatunku antymisów”41. We wrześniu 1943 roku zapowiedziano wizytę biskupa Sawy w Londynie, który miał z rządem polskim unormować duszpasterstwo wojskowe w Armii Polskiej oraz nawiązać kontakt ,z obywatelami polskimi wyznania prawosławnego, znajdującymi się w liczbie przeszło 3000 osób na Bliskim Wschodzie"42.

Zmiana sytuacji militarnej, objęcie funkcji naczelnego wodza przez generała Kazimierza Sosnkowskiego oraz powołanie przez rząd polski w Londynie Wojskowego Ordynariatu Prawosławnego zmieniło położenie ludności cywilnej przebywającej na terenie Iranu. Decyzją władz wojskowych ludność cywilna została ewakuowana z Iranu do Afryki i innych krajów azjatyckich. Szykanowany przez znajdujących się w obozach na terenie Teheranu Polaków ksiądz Michał Bożerianow zdecydował się na wyjazd z wiernymi do Tanzanii w końcu marca 1943 r. Duchowny z powodu swojej narodowości i przekonań nie zechciał zostać kapelanem wojskowym w armii generała Władysława Andersa. Według relacji ówczesnych prawosławny duchowny stracił nadzieję na kontakt ze swoją rodziną ${ }^{43}$. Nie udało się opuścić ZSRR jego małżonce, którą wyrzucił z transportu polski oficer jako osobę nie podlegającej ewakuacji. O tym fakcie duchowny $\mathrm{z}$ wielkim żalem sam dwa lata później napisał: „W momencie, kiedy otrzymywałem listy

\footnotetext{
${ }^{40}$ Cyt. za: J. Grzybowski, Białorusini $w$ polskich regularnych formacjach wojskowych $w$ latach 1918-1945, s. 374.

${ }^{41}$ Arcybiskup generat brygady Sawa (Jerzy Sowietow), Aneks 3.

${ }^{42}$ Arcybiskup generat brygady Sawa (Jerzy Sowietow), Aneks 4.

${ }^{43}$ M. Szwedziuk, Bełarusy u Afrycy w 1942-1948 godach, „Bełarus”, nr 450, Nju Jork 1998
} 
pełne uznania i podziękowania za moje obywatelskie stanowisko, w tym samym momencie, jak gdyby na ironię, żona moja zostaje brutalnie wyrzucona $\mathrm{z}$ transportu obywateli polskich, mających być ewakuowanymi z Rosji do Iranu. Pozostaje więc w Rosji. Pozostaje tylko dlatego, że jest prawosławną i że jest żoną »popa prawosławnego«. Tak to zrozumiał głoszone przez ówczesny rząd R.P. hasło równości obywatelskiej bez różnicy wyznania - ten 》)szlachetny« kierownik wspomnianego transportu, wyrzucając moją żonę z pociągu"44. Ks. Michał Bożerianow już nigdy więcej nie zobaczył swojej żony.

Duchowny nie zaprzestał działalności politycznej. Nadal przewodniczył Komitetowi Białoruskiemu. To w jego imieniu wysłał list do nowego premiera Stanisława Mikołajczyka., w którym wyrazili głęboki żal z powodu tragicznego zgonu gen. Sikorskiego. „Generał Sikorski był Wodzem nie tylko Polskich Sił Zbrojnych, ale był jednocześnie Wodzem wszystkich obywateli polskich. My, Białorusini, widzieliśmy w Nim i swego, białoruskiego wodza; wszyscy dobrze wiemy ile dobrego serca i najlepszych chęci miał w sobie ś.p. Premier i Naczelny Wódz dla nas, Białorusinów. Śmierć ś.p. Generała Sikorskiego jest niepowetowaną stratą dla narodu Polskiego, ale bynajmniej nie mniejszą stratą jest dla nas, Białorusinów. W osobie ś.p. Generała Sikorskiego straciliśmy Wielkiego Męża Stanu, który poświęcając wszystkie swoje siły dla dobra i rozkwitu Rzeczypospolitej Polskiej doprowadziłby nas do rozwoju i dobrobytu kulturalno-oświatowego, opartego na zupełnej równości, sprawiedliwości i demokracji. W osobie Pana Premiera zapewniamy Rząd Rzeczypospolitej Polskiej, że tragiczna śmierć ś.p. Generała Sikorskiego spowodowała prawdziwą, głęboką żałobę w sercach naszych, Białorusinów. Niepowetowana utrata Wodza Polaków i Białorusinów spowoduje jeszcze większy wysiłek Narodu Białoruskiego w walce o Niepodległość i rozkwit Sprawiedliwej, Demokratycznej, Potężnej i Niepodległej Rzeczypospolitej Polskiej wraz ze wszystkimi jej ziemiami i obywatelami. Gorąco prosimy Pana Premiera Rządu RP wyzyskać nas, Białorusinów, w całej pełni, by pokazać światu, iż jesteśmy z Polakami, mamy swoją własną wolę i z własnej swobodnej woli pragniemy związać nasze życie i losy z losem Rzeczypospolitej Polskiej. Niech obca a wroga Polsce propaganda zostanie rozpoznana w swoim kłamstwie, a Świat ujrzy istotną prawdę i nasze istotne dążenie przynależeć wyłącznie do Polski (...) ${ }^{\text {,45 }}$.

Następnym krokiem ks. Bożerianowa i jego zwolenników stał się list do nowego premiera. W deklaracji wysłanej w lipcu 1943 r. na ręce S. Mikołajczyka, czytamy: „Białorusini, w druzgocącej masie swej chłopi, od setek lat związani są z chłopami polskimi nie tylko pracą na roli, wspólną z nami obroną Niepodległości naszej i ich, wspólną o Nią walką, ale także więzami rodzinnymi, które zespalają nas, chłopów białoruskich, z chłopami polskimi $\mathrm{w}$ jedną serdeczną i solidarną rodzinę, jak braci. My, Białorusini, oświadczamy, iż kochamy nasz Polski Kraj, naszą Polską Ziemię i z całej duszy pragniemy jej największego rozkwitu i dobra. Jesteśmy przywiązani do Polski i do polskiego chłopa $\mathrm{i}$ we wszystkim solidaryzujemy się z nim i pracami Stronnictwa Ludowego w Kraju okupowanym, jak i Jego przedstawicielami w Rządzie Rzeczypospolitej i Radzie Narodowej na Emigracji. Praca Stronnictwa Ludowego i Jego Przywódców prowadzi do rozkwitu Polski, do rozkwitu całego włościaństwa

\footnotetext{
${ }^{44}$ M. Bożerianow, Moja odpowiedź „ludziom malym”, s. 20.

${ }^{45}$ Cyt. za: J. Grzybowski, Białorusini $w$ polskich regularnych formacjach wojskowych $w$ latach $1918-1945$, s. 375.
} 
Rzeczypospolitej, a więc i do naszego rozkwitu i pomyślności. Toteż Stronnictwo Ludowe jest stronnictwem zupełnie bliskim i drogim nam, Białorusinom, a zatem z całego serca pragniemy jego rozkwitu i potęgi. Zapewniając o tym Pana premiera Rządu RP, prosimy o zaliczenie nas do grona członków Stronnictwa Ludowego i opiekę nad nami tak jak nad chłopami polskimi ją spełniacie. My zaś według starego swego zwyczaju chłopskiego prosić będziemy Boga, by błogosławił ciężki trud Pana Premiera dla odzyskania Niepodległości naszej Ojczyzny - Rzeczypospolitej Polskiej, jak i wysiłek o Jej demokratyczny i sprawiedliwy dla wszystkich, a więc i dla nas, Białorusinów, ustrój ${ }^{\prime 46}$.

Głównym celem Komitetu było uzyskanie dla Białorusinów miejsca w Radzie Narodowej: „Białorusini, obywatele polscy zamieszkali w Afryce Wschodniej i Indiach zwracają się do Pana Premiera z gorącą prośbą zezwolić nam mieć swego białoruskiego przedstawiciela w Radzie Narodowej przy Rządzie Polskim w Londynie. Prosimy o to bardzo, szczególnie teraz, kiedy obcy imperializm dąży do oderwania nas od Polski, okłamując cały Świat cywilizowany, iż rzekomo Białorusini pragną należeć do Związku Radzieckiego. Pragniemy przez swego przedstawiciela w Radzie Narodowej wyświetlić Europie i Ameryce istotny stan i naszą istotną wolę wchodzić w skład Rzeczypospolitej Polskiej wyłącznie. Jedną z głównych przyczyn agresji sowieckiej w stosunku do nas i do Ziem Polskich przez nas zamieszkałych - jest przede wszystkim postanowienie i dążenie Rosji zlikwidować „Piemont” białoruski, którym właśnie są Białorusini w Polsce. „Piemont” białoruski w Polsce jaskrawo świecił dobrobytem i wolnością ludu białoruskiego - co wabiło Związek Sowiecki, gdzie istotny ruch narodowy jest gnębiony i Białorusini żyją w nędzy i strachu, niepewni swego losu, niepewni swego dnia jutrzejszego pod despotyczną władzą Moskwy. Moskwa pragnie za wszelką cenę zlikwidować ten białoruski „Piemont” w Polsce, bowiem on otwiera oczy Białorusinom Sowieckim na rzeczywisty stan, wskazując o ileż szczęśliwszymi są Białorusini w Rzeczypospolitej Polskiej i o ileż wyższym jest ich poziom kulturalny i stopień rozwoju $(\ldots)^{\text {,47 }}$

Polscy politycy na emigracji kilkakrotnie próbowali wprowadzić do Rady Narodowej kilku przedstawicieli mniejszości narodowych. Według Jerzego Grzybowskiego w 1940 r. we Francji władze polskie rozważały kandydature Fabiana Jeremicza ${ }^{48}$ jako reprezentanta mniejszości białoruskiej w Radzie Narodowej R.P. Latem 1942 r., ambasador R.P. w ZSRR Stanisław Kot zaproponował dwóch kandydatów ze strony białoruskiej. Byli to Feliks Hołowacz ${ }^{49}$, były członek klubu „Wyzwolenie” i prawosławny

\footnotetext{
${ }^{46}$ Cyt. za: J. Grzybowski, Białorusini $w$ polskich regularnych formacjach wojskowych $w$ latach 1918-1945, s. 376.

${ }^{47}$ Tamże, s. 376-377.

${ }^{48}$ Fabian Jeremicz ur. 18 stycznia 1891 r. w Dulowcach (pow. Wołkowysk), białoruski działacz polityczny, w latach 1922 - 1935 poseł na sejm I, II i III kadencji. Członek zarządu Instytutu Białoruskiej Gospodarki i Kultury, wiceprezes Białoruskiego Centrum Włościańskiego. W latach 30. osadnik wojskowy i członek Związku Osadników.

${ }^{49}$ Feliks Hołowacz, ur. 4 lipca 1886 r. w Zaborzu (pow. Wołożyn) - zm. 27 lutego 1972 r. we Wrocławiu. Białoruski działacz polityczny, początkowo działał w PSL „Wyzwolenie”, następnie związał się z lewicową opozycją i w październiku 1923 r. uczestniczył w Moskwie w konferencji powołującej do życia Międzynarodówkę Chłopską. Poseł na sejm I kadencji 1922 - 1927. Aresztowany w 1927 r. i na mocy decyzji sejmu z 4 lutego 1927 r. wydany sądom ,za udział w spisku na ustrój i całość Rzeczypospolitej”. Zwolniony bez wyroku sądowego. Do wybuchu II
} 
duchowny Henadzi Szymanowski ${ }^{50}$. Również inne partie i stronnictwa występowały z propozycją wprowadzenia do Rady Narodowej przedstawiciela Białorusinów. 3 kwietnia 1945 r. grupa londyńskich piłsudczyków wysłała list do prezesa Rady Ministrów z propozycją wprowadzenia jednego przedstawiciela Białorusinów do Rady Narodowej argumentując: „fakt, że około 60 procent ogółu ludności tych ziem nawet w czasach przedwojennych stanowiła ludność niepolska, przede wszystkim białoruska i ukraińska, jest argumentem, który może być wykorzystany przeciwko stanowisku polskiemu",51. Mimo powyższych propozycji rząd polski nie brał pod uwagę możliwości udziału w życiu politycznym działaczy Komitetu Białoruskiego i nie odniósł się do deklaracji uchodźców polskich narodowości białoruskiej. Premier Mikołajczyk ograniczył się do podziękowania im za gotowość do walki o niepodległość Polski i zapewnił, że prawa ludności białoruskiej będą uwzględnione w powojennej Rzeczypospolitej.

W latach 1942-1943 polscy uchodźcy zostali przeniesieni z Iranu do Afryki Wschodniej (23 676 osób), Indii (4 701), Palestyny (6 569), Meksyku (1 569), Nowej Zelandii (838) i innych krajów. W czasie pobytu w Iranie zmarło ponad 2 tys. cywilnych obywateli polskich $^{52}$. Nie jest możliwe dokładne ustalenie liczby Białorusinów w poszczególnych grupach. Wielu Białorusinów znalazło się w Indiach, na co wskazują osoby o nazwiskach białoruskich, pochodzących z kresów północno-wschodnich ${ }^{53}$. Więcej informacji zachowało się na temat Białorusinów, którzy po pobycie na terenie Iranu znaleźli się w Afryce Wschodniej. W październiku 1942 r. do Afryki wyjechało około 900 obywateli polskich wyznania prawosławnego. W kwietniu 1943 r. w Obozu Uchodźców Polskich nr $1 \mathrm{w}$ Iranie pozostało nadal ok. 800 prawosławnych.

Na terenie Afryki Wschodniej założono 18 obozów dla uchodźców polskich, w tym Tengeru (Tanzania), Rongai (Kenia), Lusaka (Rodezja Północna), Koja, Masindi (Uganda) $\mathrm{i}$ inne. $\mathrm{W}$ osiedlach tych mieszkali uchodźcy polscy bez względu na wyznanie $\mathrm{i}$ narodowość. Według Konsulatu Generalnego R.P. w Nairobi podział narodowościowowyznaniowy kształtował się następująco: „ogromna większość Polaków-kresowców, trochę Białorusinów i Ukraińców. Minimalny procent Żydów. Ścisłe określenie składu narodowościowego jest prawie niemożliwe, narodowość może być jedynie zgadywana. To samo odnosi się do sprawy wyznań. Słyszałem niejednokrotnie o dziwnych i smutnych

wojny światowej wójt gminy Mir (pow. Nie- śwież). W 1939 r. aresztowany przez NKWD i wywieziony w głąb ZSRR. Pracował jako dozorca w Domu Dziecka w Dżambule (Kazachstan), od 1943 r. był członkiem Związku Patriotów Polskich. W 1946 r. wrócił do Polski.

${ }^{50}$ Władze polskie uważały Szymanowskiego za Polaka wyznania prawosławnego, który „w razie potrzeby mógłby uchodzić za Białorusina", tymczasem sam Szymanowski czuł się Białorusinem kultury polskiej. G. Szymanowski, Dwanaście lat - wspomnienia z lat 1927 - 1939, Toruń, 1998, s. 120.

${ }^{51}$ Cyt. za: J. Grzybowski, Białorusini $w$ polskich regularnych formacjach wojskowych $w$ latach 1918-1945, s. 378.

${ }^{52}$ Polacy w Iranie 1942 - 1945, t. I., Antologia, pod red. A. Kunert, A. Przewoźnik, Warszawa 2002, s. 411.

${ }^{53}$ Polacy w Indiach 1942 - 1948 w świetle dokumentów $i$ wspomnień, pod red. L. Betgowski, Warszawa 2002, s. 752-756. O Polakach w Nowej Zelandii, por.: Polacy w Nowej Zelandii, wspomnienia deportacji do ZSRR, Welligton 1980; Dwie ojczyzny. Polskie dzieci w Nowej Zelandii. Tułacze wspomnienia, pod red. S. Manterysa, Warszawa 2006. 
objawach zatajania czy też ukrywania swego wyznania przez prawosławnych i grekokatolików i podawania się za katolików. Jest to urojony kompleks obawy „stracenia polskości” i wiąże się ściśle ze stanowiskiem tamtejszego (i niestety - nie tylko tamtejszego) kleru katolickiego: co polskie - to katolickie. (...) Wprowadzono nawet pojęcie »mniejszość« kierując się kategoriami wyznania (...) ${ }^{, 54}$.

Cywilów znajdujących się na terenie Afryki spotkały nowe warunki klimatyczne, nieznane środowisko, afrykańskie choroby. Osiedlono ich w prowizorycznych obozach, w których zapewniono im bezpłatne utrzymanie, stałą opiekę medyczną i szkoły dla dzieci. Młodzież skierowano do szkół polskich: średnich i początkowych. Dorośli mogli dorabiać dorywczo przy pracach sezonowych u miejscowych Greków. Jeden z największych obozów w Afryce znajdował się w Tengeru w Tanzanii (Tanganice), koło miasteczka Arusha. Liczył on ponad 4000 osób. W obozie tym przebywało wielu prawosławnych Białorusinów, przeważnie niezdolnych do służby wojskowej mężczyzn, kobiety i dzieci. Szacuje się, że ponad czterysta prawosławnych Białorusinów znajdowało się w obozie w Tengeru.

Do obozu w Tengeru koło miasteczka Arusha w Tanzanii ksiądz Michał Bożerianow przybył dopiero lipca 1943 r., pomimo, że dokumenty o wyjazd złożył już w marcu tego roku. Duchowny i jego współpracownica Ludmiła Szewczuk padł ofiarą prowokacji polskiej „dwójki” czyli wywiadu wojskowego. Bezpodstawnie oskarżono ks. Bożerianowa i pracownicę poczty o kradzież listów. Prowokacja spowodowała zatrzymanie duchownego w porcie Ahvazie, skąd uchodźcy udawali się do Afryki. Dopiero oczyszczenie z zarzutów przez Komisję Badawczą w Iranie 19 maja 1943 r. i interwencja ministra pełnomocnego R. P. w Teheranie Karola Badera doprowadziło do uwolnienia zatrzymanych. Ks. M. Bożerianow uzyskał wolność po 54 dniach zatrzymania przez Straż Bezpieczeństwa. Sam te wydarzenie ocenił jako prowokację i wyraz antybiałoruskiej fobii przebywający na terenie Iranu służb polskich, które działy wbrew polityce rządu w Londynie. „Dla zażegnania tego bezprawia o podłożu czysto politycznym, przybył do Ahvazu Delegat Ministerstwa Spraw Wewnętrznych mgr. Jerzy Górszczyk $^{55}$, który wygłosił przemówienie do ludności prawosławnej po nabożeństwie w kaplicy w Ahvazie, w którym przyznał, iż ich duszpasterzowi (tj. mnie) wyrządzono straszną krzywdę itd...W tym czasie p. Sz.[ewczuk] nie została jeszcze zwolniona. W parę dni po tym otrzymałem pismo Komisji Badawczej w Iranie, które stwierdza w całej swej rozciągłości, fakt bezprawia dokonanego na mnie przez ludzi »>szlachetnych «"56.

Przed opuszczeniem Ahvazu w lipcu 1943 r. władze duchowne powołały ks. Bożerianowa na stanowisko Prawosławnej Cerkwi Polskiej Inspektora Religijnego na Centralną i Wschodnią Afrykę. Był on jedynym księdzem prawosławnym na terenie polskich osiedli w Afryce. Początkowo duchowny adaptował jeden z budynków obozowych na kaplicę w Tengeru, a następnie przy pomocy miejscowych Greków wybudował cerkiew, w której zgromadził zebrane przez wiernych ikony. Część ikon napisał włoski malarz, który przebywał w obozie jako jeniec wojenny. Parafianami księdza Bożerianowa stali się przebywający w obozie Białorusini, Polacy, Ukraińcy i

\footnotetext{
${ }^{54}$ Cyt. za: J. Grzybowski, Białorusini $w$ polskich regularnych formacjach wojskowych $w$ latach $1918-1945$, s. 380

55 Jerzy Górszczyk, delegat Ministerstwa Spraw Wewnętrznych i Stronnictwa Ludowego w Palestynie (1943-95).

${ }^{56}$ M. Bożerianow, Moja odpowiedź ,,ludziom matym”, s. 19.
} 
miejscowi Grecy. Ksiądz Michał zorganizował dwa chóry parafialne, w tym chór dziecięcy. Prawosławna młodzież znalazła zatrudnienie w kancelarii parafialnej i drukarni. Z pośród tej młodzieży wyrosło wielu duszpasterzy, którzy pracowali wśród białoruskiej emigracji. Ksiądz Włodzimierz Moroz był dziekanem w Anglii (zm. 1994 r.), a ksiądz Włodzimierz Zajka był duszpasterzem w Australii ${ }^{57}$. W celu integracji młodzieży duchowny zorganizował dla niej klub, w którym urządzał coniedzielne spotkania.

Ksiądz Michał prowadził ożywioną działalność duszpasterską. Kapłan odwiedzał inne obozy w Afryce, gdzie mieszkali prawosławni. Jego opieka duszpasterska pomogła wielu przetrwać załamania duchowe. Podczas kazań ks. Bożerianow mówił swym współwyznawcom: „Nie jesteście gorsi od katolików, dlatego musicie mieć jednakowe prawa jako obywatele polscy". Duchowny miał wsparcie polskiego konsula Konsulatu Generalnego RP w Nairobi - Władysława Kowalskiego ${ }^{58}$. W jego raporcie z 11 sierpnia 1943 r. znajduje się informacja o duchownym prawosławnym. „Ks. Bożerianow jest mi osobiście dobrze znany i uważam go za bardzo pozytywny i szlachetny typ człowieka, który $\mathrm{z}$ racji swoich funkcji duszpasterskich ogromnie dużo dobrego może zrobić w naszych osiedlach. Jest on bardzo patriotycznie nastawiony i uważam, że należy go w jego działalności społecznej i patriotycznej jak najbardziej popierać"59.

Duże znaczenie w pracy duszpasterskiej miało wydanie przez księdza Bożerianowa w Nairobi (Kenia) modlitewnika w 1944 roku. Duchowny wydał modlitewnik dzięki wsparciu finansowemu Konsulatu Generalnego RP w Nairobi. Modlitewnik był napisany w języku cerkiewno-słowiańskim $\mathrm{z}$ polską transliteracją i polskojęzycznymi objaśnieniami. Modlitewnik zawierał modlitwy dzienne i wieczorne, porządek liturgii świętej, wieczerni, tropariony, akafisty, kalendarium świąt cerkiewnych. W modlitewniku znaleźli się między innymi: Kanon molebnyj do Jezusa Chrystusa (s. 1-8), Bogurodzicy (9-17), Anioła Stróża (18-24); akafisty; do Cudotwórcy Mikołaja (25-35), świętego Serafina Sarowskiego (36-46) i modlitwy z wieczerni pięćdziesiątnicy (47-56). Luźne wydrukowane karty, zszyte grubą nitką, stanowiły ważną literaturę religijną, pomocną duchownym i wiernym w modlitwach. Modlitewnik ten stał się najbardziej popularną książką religijną $\mathrm{w}$ środowisku emigracyjnym prawosławnych Białorusinów. W latach powojennych jego egzemplarze można było spotkać wśród prawosławnych emigrantów w Wielkiej Brytanii, Kanady, Stanach Zjednoczonych i Australii. Z obozowej drukarni w Tenegeru księdza Michała wyszły podręczniki do nauczania religii, śpiewu i inna literatura cerkiewna.

Podobnie jak terenie obozów uchodźców w Iranie również w Afryce Wschodniej zaczęła rozwijać się wśród osób narodowości polskiej nienawiść do Ukraińców i Białorusinów. Przedstawicieli obu narodów oskarżano o wywózki w latach 1939-1941, zapominając, że to Białorusini i Ukraińcy byli też ofiarami sowieckich deportacji. Oskarżano też wyznawców prawosławia o okupację sowiecką kresów wschodnich II Rzeczypospolitej, nie uwzględniając faktu, że Białorusinów nikt o zdanie nie pytał. Postawy antymniejszościowe dominowały wśród ludności narodowości polskiej pomimo, że ponad dwa tysiące Białorusinów walczyło w polskich formacjach wojskowych na

\footnotetext{
${ }^{57}$ J. Grzybowski, Białorusini w polskich regularnych formacjach wojskowych $w$ latach 1918-1945, s. 382; M. Szwedziuk, Białorusini w Afryce w latach 1942-1948, s. 14.

${ }^{58}$ Konsul honorowy w Nairobi w latach 1943-1945.

${ }^{59}$ Cytat za: J. Grzybowski, Białorusini w polskich regularnych formacjach wojskowych $w$ latach $1918-1945$, s. 383.
} 
Zachodzie a większość znajdujących się w obozach prawosławnych wykazywało lojalny stosunek do państwa polskiego. Narastanie tendencji antyprawosławnych doprowadziło do napadów na budynki zamieszkałe przez Białorusinów i do dewastacji cerkwi.

Postawę ludności polskiej trudno wytłumaczyć klęską wrześniową w 1939 r. czy latami okupacji Radzieckiej. Poczucie krzywdy wzbudziły wśród uchodźców-Polaków nienawiść do prawosławnych Białorusinów. Mieszkając w Afryce, Polacy traktowali jako zjawisko wrogie kulturze polskiej wyznanie prawosławne, nabożeństwa $\mathrm{w}$ innych językach słowiańskich, niepolską gwarę. Pomimo że, uchodźcy narodowości białoruskiej byli nastawieni pozytywnie do Polski, to wśród Polaków utrwaliło się przekonanie o antypolskiej i prosowieckiej postawie całej społeczności białoruskiej. Przedstawiciele Konsulatu R.P. byli zdania, że głównym powodem nieprzychylnej postawy części katolików do prawosławnych było duchowieństwo rzymskokatolickie. Potwierdzeniem tego faktu jest fragment sprawozdania Konsula RP w Nairobi: „Jeżeli powiedzenie: duchowieństwo katolickie w Afryce utrzymuje polskość słuszne, to pozostaje pytanie: jaką polskość? Nastawienie duchowieństwa jest szowinistyczne. Na pierwszym miejscu są stawiane sprawy wyznania, sprawy kościoła katolickiego, a dopiero dalej sprawa polska. Zwracam jeszcze raz uwagę, że właściwie jedynym autorytetem w obecnej sytuacji w osiedlach jest - ambona, i autorytet ten nie zawsze jest należycie wykorzystywany(...)",60.

Po wpływem tych wydarzeń, obelg i wrogiej postawy duchowieństwa katolickiego wobec prawosławnych ks. Bożerianow rozpoczął wydawać czasopismo „Promyk Prawosławny". Czasopismo miało integrować społeczność prawosławną w Afryce. „Promyk Prawosławny” był wydawnictwem Prawosławnego Duszpasterstwa Polskiego w Afryce. Ulotka była skierowana „do prawosławnych uchodźców, obywateli polskich”, którzy znaleźli się w Tanzanii (Tanganice) i innych regionach Afryki. Pierwszy numer „Promyka Prawosławnego” ukazał się w połowie kwietnia 1943 roku. Pismo wychodziło jako dwutygodnik aż do końca 1945 roku. Czasopismo ukazywało się z jakże wymownym mottem „Jeśli Cerkiew nie jest ci matką to i Pan Bóg nie będzie ci ojcem”. Głównym celem wydawnictwa było zachęcenie wiernych do jednoczenia się wokół Cerkwi prawosławnej, uczestniczenia w modlitwie, poznawania zasad wiary chrześcijańskiej. W nagłówku znajdowało się równie wymowne na ówczesne czasy pouczenie: „Nie niszcz tych ulotek, szanuj słowo Boże". Z drugiej strony ulotki znajdujemy kolejny apel redaktora: „Po przeczytaniu ulotkę tę pożycz innym, a następnie weź ją z powrotem niech będzie Ci pamiątką i pocieszeniem w przyszłości”. Treść ulotki, oprócz stopki redakcyjnej, kończyła się hasłem: „Z Bogiem do Ojczyzny”.

Przez trzy lata ojciec Michał Bożerianow prowadził wśród uchodźców poprzez „Promyk Prawosławny” katechezę. W numerze 5 (46) „Promyka Prawosławnego” z 1945 roku znajdujemy „pouczenie z klasztoru św. Eliasza na Atosie” na temat modlitwy wewnętrznej i rozważania o Bogu. $\mathrm{W}$ numerze $6 \mathrm{z}$ tego roku zamieszczone zostało pouczenie ,jak zachowywać się w świątyni Bożej”. Następne dwa numery byli poświęcone kwestiom historycznym i polemicznym. Bożerianow przetłumaczył z języka francuskiego artykuł księcia Włodzimierza Bariatyńskiego opublikowanego w Paryżu w 1939 roku o „Papieżycy Janinie” . Praca ta była poświęcona kobiecie, która według historyków zasiadała w IX wieku na tronie papieskim. Mieszkający w obozie katolicy protestowali przeciwko publikacjom ks. Michała Bożerianowa, zwłaszcza przeciwko

\footnotetext{
${ }^{60}$ Cytat za: J. Grzybowski, Białorusini $w$ polskich regularnych formacjach wojskowych $w$ latach
} 1918-1945, s. 383. 
„Papieżycy Janinie”. Duchowieństwo katolickie po ukazaniu się tego numeru czasopisma groziło zemstą wierzących Polaków ${ }^{61}$.

Pozostałe numery z 1945 roku zostały poświęcone głównie kwestiom teologicznym i katechetycznym. Z uwagi na brak wcześniejszych egzemplarzy ulotek możemy jedynie przypuszczać, że ich treść i charakter nie odbiegała od zachowanych.

Po klęsce deklaracji i memoriałów, które nie doczekały się odpowiedzi od rządu polskiego oraz niewłaściwego stosunku uchodźców-katolików do jego współwyznawców, nastąpiła zmiana poglądów ks. Bożerianowa. Sprawą konfliktów w obozie w Tangeru interesował się Konsul Generalny RP w Nairobi. W jednym z raportów pisał: „Na terenie Afryki jest tylko jeden ksiądz prawosławny, ks. M. Bożerianow. Nie mam żadnych kwalifikacji by zabierać głos i wyrażać zdanie w zatargach religijnych, zaznaczam jedynie, że zatargi wyznaniowe tam są powodem wprowadzenia pojęcia mniejszości. (...) $\mathrm{Na}$ terenie Afryki słyszałem z ust ks. Bożerianowa szereg skarg na panujące tam stosunki, na niewłaściwy stosunek do jego współwyznawców, do niego i do jego pracy. Nie przytaczam tych zarzutów, są bowiem jednostronnym naświetleniem, ale fakt spalenia w nocy domu, w którym on się zatrzymywał wizytując współwyznawców (osiedle Koja, listopad 1945 roku) mówi wiele. (...) Przytaczam powyższe w celu zilustrowania stosunków wyznaniowych w Afryce oraz jako przykład tego - jak można zmarnować dla sprawy człowieka, praca którego mogła być cenna" ${ }^{\text {"62 }}$. Rzeczywiście propolsko nastawiony ks. M. Bożerianow, organizator Komitetu Białoruskiego w Iranie, zwolennik porozumienia z Polakami, stał się obiektem ataku polskich kół narodowych. Fakt ten spowodował zmianę stanowiska duchownego $\mathrm{z}$ polonofilskiego na zwolennika niezależnego ruchu białoruskiego. Pod wpływem doznanych krzywd ks. M. Bożerianow i inni członkowie Komitetu Białoruskiego zerwali współpracę z Polakami i zaczęli tworzyć na emigracji własne organizacje narodowe.

W połowie 1946 roku ksiądz Michał Bożerianow zaczął chorować na nerki i trafił do szpitala w Dar es Salaam w Tanzanii. Wyszedłszy ze szpitala duszpasterz powrócił do obozu w Tangeru. Zmarł wśród swoich wiernych 20 sierpnia 1946 roku, nie ukończywszy 35 roku życia. Jego parafianie i miejscowi Grecy postawili na jego grobie w Dar es Salaam wspaniały pomnik z napisem w języku angielskim. Kiedy w 1948 roku rozpoczęto likwidację obozu, jego parafianie po raz ostatni oddali cześć swemu duchownemu. O wielkim autorytecie, jakim cieszył się ojciec Michał Bożerianow wśród wiernych świadczy fakt, że pozostał on na trwale w pamięci białoruskich i polskich emigrantów przebywających w Wielkiej Brytanii, Włoszech, Stanach Zjednoczonych, Kanadzie, Australii i Południowej Afryce. Wydawnictwa przygotowane i wydane drukiem przez oddanego wiernym duchownego były powszechnie wykorzystywane w nabożeństwach prawosławnych w środowisku emigrantów polskich, białoruskich i ukraińskich. Dla wielu pozbawionych stałej opieki duszpasterskiej były jedynym źródłem nauki modlitwy i poszerzenia wiedzy religijnej. Katechizmy, modlitewniki i pisma księdza Michała Bożerianowa odegrały ważną rolę w podniesieniu stanu świadomości religijnej obywateli polskich na obczyźnie wyznania prawosławnego.

Ks. Michał Bożerianów widział we współpracy $\mathrm{z}$ rządem polskim szansę na odzyskanie niepodległości i odbudowy kraju w którym Białorusini i Polacy i inne

\footnotetext{
${ }^{61}$ M. Szwedziuk, Bełarusy u Afrycy w 1942-1948 godach, „Ruń, nr 29.

${ }^{62}$ Cyt. za J. Grzybowski, Białorusini $w$ polskich regularnych formacjach wojskowych $w$ latach 1918-1945, s. 383.
} 
mniejszości mieli by takie same prawa. Deklaracja lojalności nie wzbudziły zainteresowania rządu polskiego i rządów państw zachodnich. Rząd polski na uchodźstwie nie zwracał uwagi na opinie obywateli polskich narodowości białoruskiej w udowodnieniu swych pretensji do ziem Zachodniej Białorusi. Dla rządów państw zachodnich, w warunkach toczącej się wojny, problem białoruski nie stanowił istotnego znaczenia. Uważano w przyszłości, że ziemie białoruskie będą stanowić problem wewnętrzny ZSRR. Wrogo do duchownego prawosławnego i działalności Komitetu Białoruskiego odniosło się środowisko polskich uchodźców.

\section{BIBLIOGRAFIA}

\section{ŹRÓDŁA}

[1] Archiwum Instytutu Polskiego i Muzeum im. gen. Sikorskiego w Londynie, Dokument cywilnych urzędów rządowych 1919-1991, Inwentarze, sygn. akt. A. 20, 4a, nr-y: 138, 140.

[2] Archiwum Instytutu Polskiego i Muzeum im. gen. Sikorskiego w Londynie, Prezydium Rady Ministrów, sygn. akt. A. 80, nr-y: 23-25.

[3] Archiwum Warszawskiej Metropolii Prawosławnej w Warszawie, Akta personalne księży, R IV-6A, nr 1092; R II6C/188.

[4] Arcybiskup generat brygady Sawa (Jerzy Sowietow). Wybór dokumentów, opr. K. Filipow, i A. Suchcitz, Białystok-Warszawa 1997.

[5] Bożerianow M., Moja odpowiedź „ludziom małym”, Tengeru, Arusha, Tanganyika 1945.

[6] „Dziennik Urzędowy Zarządu Cywilnego Ziem Wschodnich”, R. II., 1920, nr 47.

[7] Polacy w Iranie 1942 - 1945, t. I., Antologia, pod red. A. Kunert, A. Przewoźnik, Warszawa 2002.

[8] Polacy w Indiach 1942 - 1948 w świetle dokumentów $i$ wspomnień, pod red. L. Betgowski, Warszawa 2002.

[9] Rozporządzenie Rady Ministrów z 9 stycznia 1926 r. o przymusowym wykupie ziemi w powiecie brasławskim (druk)

[10],Воскресное Чтение”, nr-y: 20, 22, 38, 40, Warszawa 1937.

[11],Слово”. Wydawnictwo Prawosławnej Metropolii w Warszawie, nr-y: 34, 43, 44, Warszawa 1936.

\section{LITERATURA}

[1] Арх. Афанасий Мартос, Беларусь в исторической, государственной и церковной жизни, Buenos-Aires 1966.

[2] Boćkowski D., Deklaracja lojalności obywateli polskich narodowości białoruskiej dla gen. Władysława Sikorskiego, „Mazowieckie Studia Humanistyczne", Rocznik II, Łowicz 1996, nr 2.

[3] Dubec R. Ks., Z dziejów parafii prawosławnych na Łemkowszczyźnie w okresie międzywojennym, Gorlice 2011.

[4] Dymarski M., Białorusini z armia gen. Andersa. Przyczynek do dziejów ludności Kresów Wschodnich, [w:] Tematy polsko-białoruskie. Historia - literatura edukacja, Olsztyn 2003. 
[5] Eberhard P., Polski panslawizm jako idea geopolityczna, „Przegląd Geopolityczny", t. VII, 2014.

[6] Grzybowski J., Białorusini w polskich regularnych formacjach wojskowych $w$ latach 1918-1945, Warszawa 2006.

[7] Grzybowski J., Białorusini wśród uchodźców polskich na Środkowym Wschodzie $i$ w Afryce Wschodniej w czasie II wojny światowej, „Pamięć i Sprawiedliwość”, $2005, \mathrm{nr} 2$.

[8] Kalbarczyk S., Polscy pracownicy nauki ofiary zbrodni sowieckich w latach II wojny światowej zamordowani, więzieni, deportowani, Warszawa 2001.

[9] Kasiak I., Byelorussia. Historical Outline, London 1989.

[10]Касьяк И., 3 хистории Праваслаунай Царквы Беларускага народу, New York 1956.

[11]bp. Miron (Chodakowski), Z dziejów prawosławnego ordynariatu wojskowego $w$ Rzeczypospolitej, [w:] Chrześcijaństwo - Kościót - Prawosławie, Białystok 2003.

[12]Mironowicz A., Białoruska Autokefaliczna Cerkiew Prawosławna na emigracji po II wojnie światowej, [w:] Autochtoniczne mniejszości na pograniczach a ich stosunki $z$ odseparowanym etosem macierzystym, pod red. S. Jackiewicza, Białystok 2009.

[13]Mironowicz A., Kościót prawosławny na terenach Generalnego Gubernatorstwa w latach 1939-1944, [w:] Kościól w obliczu totalitaryzmów. Zbiór studiów dla uczczenia XXV rocznicy męczeńskiej śmierci księdza Jerzego Popiełuszki, pod red. W. Polaka, W. Rozynkowskiego, M. Białkowskiego i J. Kufla, Toruń 2010.

[14]Mironowicz A., Kościót prawosławny na terenach Generalnego Gubernatorstwa, Białorusi i Ukrainie $w$ latach 1939-1944, [w:] Pokazanie Cerkwi prawdziwej. Studia nad dziejami i kultura Kościoła prawosławnego w Rzeczypospolitej, Białystok 2004.

[15] Mironowicz A., Kościót prawosławny w Polsce, Białystok 2006.

[16] Mironowicz A., Kościót prawosławny na ziemiach polskich w XIX i XX wieku, Białystok 2005.

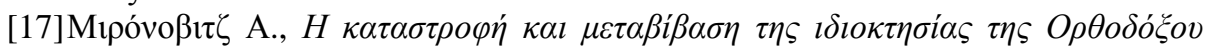

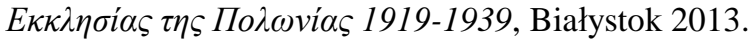

[18] Mironowicz A., Ks. Michat Bożerianow i jego działalność w Iranie i na terenie Afryki Wschodniej, „Białoruskie Zeszyty Historyczne”, nr 42, Białystok 2014.

[19]Mironowicz A., Neounia w II Rzeczypospolitej, [w:] Kościót Greckokatolicki na Warmii i Mazurach, pod red. M. Melnyka, Olsztyn 2006.

[20]Миронович А., Неоуния во II Речипосполитой, „Seminarium Hortus Humanitatis", vol. XV, Riga 2008.

[21]Миронович А., Неоуния в Польше в межвоенной период, „Вестник Екатеринбургской духовной семинарии”, Вып. 2(6), Екатеринбург 2013.

[22]Mironowicz A., Polskie prawosławne duszpasterstwo cywilne $w$ Afryce, „Wiadomości PAKP”, nr 5 (138), Warszawa 2001.

[23]Mironowicz A., Przyczynek do dziejów Polskiego Prawosławnego Duszpasterstwa Cywilnego na emigracji w czasie II wojny światowej, „Studia Polonijne", t. 30, Lublin 2009-2010.

[24]Mironowicz A., Rewindykacja i niszczenie prawosławnych obiektów sakralnych na terenie II Rzeczypospolitej, „Е $\Lambda \Pi І \Sigma ”$ Czasopismo Katedry Teologii 
Prawosławnej Uniwersytetu w Białymstoku, R. VIII (XIX), z. 13-14 (26-27), Białystok 2006.

[25]Mironowicz A., The Destruction and Transfer of Orthodox church Property in Poland, 1919-1939, „Polish Political Science Yearbook”, vol. XLIII, Toruń 2014.

[26]Mironowicz A., The Orthodox Church in Poland in the Twentieth Century, [in:] The Orthodox Church in Eastern Europe in Twentieth Century, ed. Christine Chaillot, Oxford - Bern 2011.

[27]Mironowicz A., Życie religijne prawosławnej emigracji białoruskiej po II wojnie światowej, „Białoruskie Zeszyty Historyczne”, nr 33, Białystok 2010.

[28] Odziemkowski J., Frątczaka S., Polskie duszpasterstwo wojskowe, Warszawa 1996.

[29] Odziemkowski J., Stużba duszpasterska Wojska Polskiego 1914-1945, Warszawa 1998.

[30]Papierzyńska-Turek M., Między tradycja a rzeczywistością. Państwo wobec prawosławia 1918-1939, Warszawa 1989.

[31]Senex, Украинска Православна Церква в часи другой свитовой вийни 19391945, Müchen 1946.

[32] Szlewis G., (Шлевис Г.), Православные храмы Литвы, Свято-Духов Монастыр, Вильнюс 2006.

[33] Sosna G., Katalog światyń i duchowieństwa prawosławnej diecezji warszawsko-

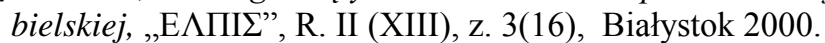

[34]Sosna G., Troc-Sosna A., Hierarchia $i$ kler Kościoła prawosławnego $w$ granicach II Rzeczypospolitej i Polski powojennej w XIX-XXI wieku, Ryboły 2012.

[35]Свитич А., Православная Церковь в Польше и её автокефалия, Buenos Aires 1959.

[36] Sziling J., Kościoły chrześcijańskie w polityce niemieckich władz okupacyjnych $w$ Generalnym Gubernatorstwie (1939-1945), Torun 1988.

[37]Шкаровский М. В., Наџыстская Германия и Православная Церковь, Москва 2002.

[38]Шкаровский М. В., Политика Третьего Рейха по отношению к Русской Православной Церкви в свете архивных материалов 1935-1945 годов, Москва 2003.

[39]Швэдзюк М., Беларусы ў Афррыцы у $1942-1948$ г2., „Беларусь”, nr 450, Nju Jork 1998. Швэдзюк М., Беларусы ў Афрыцы ў 1942-1948 г2.,, „Рунь”, nr 29, Wilno 2000;

[40]Szwedziuk M., Białorusini w Afryce w latach 1942-1948, „Polski Żołnierz Prawosławny", R V, nr 2(15), 1998.

[41] Szymanowski G., Dwanaście lat-wspomnienia z lat 1927 - 1939, Toruń 1998.

[42]Tarle E. W., Wojna krymska, t. II, Warszawa 1953.

[43]Troc-Sosna A., Ks. Michał Bożerianow, „Wiadomości PAKP”, nr 9 (154), Warszawa 2002.

[44]Turkowski R., Franciszek Wilk (1914-1990): przewodniczacy Rady Narodowej RP i przywódca polskich ludowców na uchodźstwie, Warszawa 2004.

[45]Urban K., Kościół prawosławny w Polsce 1945-1970, Kraków 1996. 
[46]Urban K., Z dziejów Kościoła prawosławnego na Łemkowszczyźnie, „Церковный Вестник”, R. XXXVIII, nr 8 (1991).

[47]Waszkiewicz Z., Duszpasterstwo w siłach zbrojnych Drugiej Rzeczypospolitej (1918-1939), Toruń 2000.

[48]Власовский И., Нарис истории украинской Православной Церкви, т. IV, ч. 2, New York 1993.

[49]Wróbel J., Uchodźcy polscy ze Zwiazku Radzieckiego 1942-1950, Łódź 2013.

[50]Wróblewski W., Duszpasterstwo mniejszości religijnych w Wojsku Polskim w latach 1918-1939, [w:] Białoruś, Czechosłowacja, Litwa, Polska, Ukraina. Mniejszości $w$ świetle spisów statystycznych XIX-XX w., pod red. J. Skarbka, Lublin 1996.

[51]Zięba A., „Wojna popów”. Polskie prawosławie na emigracji po II wojnie światowej, „Zeszyty Naukowe Wydziału Historycznego Uniwersytetu Jagiellońskiego", Kraków 1998.

\section{BELARUSIANS IN THE MIDDLE EAST AND POLISH PROBLEMS IN 1941-} 1945 IN THE WRITINGS OF REV. MICHAŁ BOŻERIANOW

Among the Polish civilians evacuated to the Soviet Union in 1942 with the army of gen. Anders there were over 2000 Orthodox Belarusians. Because the Soviet authorities would not allow non-Poles to leave the country, many Belarusians declared themselves to be Polish and Catholic. Some of them converted to Catholicism to hide their ancestry.

Because of the help they received from the Polish emigration government in leaving the Soviet Union, Belarusians felt a lot of sympathy and gratitude towards the Poles. Franciszek Wilk, a member of the National Council, helped form the Belarusian Committee, headed by rev. Michał Bożerianow, in 1942 in Iran. The Committee issued a number of memoranda and addresses to the Polish and American government, which were critical of the incorporation of the north-western regions of mid-war Poland into the Soviet Union in September 1939. Most Belarusians declared a willingness to remain Polish citizens. This attitude of Belarusian emigrants can be explained by a lack of other perspectives for the future. One of the demands made by the head of the Belarusian Committee, rev. M. Bożerianow, was to introduce a representative of the Belarusian minority to the National Council in London. The Committees weakness lay in its human resources. Belarusian emigrants included few educated people - mostly priests and teachers - with no political experience. Most of them were farmers or foresters.

In 1943 most Belarusian emigrants moved to East Africa. There the relations between emigrants deteriorated; especially between the Orthodox and the Catholics. Although most Belarusian emigrants were friendly to Poles, a stereotype emerged among the latter of antiPolish sentiments among the Belarusians. This unsubstantiated anti-Belarusian phobia led to religious conflicts in refugee camps. Religious conflicts, which continued until the camps closed, and the death of rev. Michał Bożerianow, who was the leader of the Belarusian Committee and friendly to Poles, caused most Belarusians there to change their positive attitude towards Poland and become reluctant to cooperate with Poles.

Keywords: Byelorussian, Michał Bożerianow, emigration.

DOI:10.7862/rz.2015.hss.20

Przesłano do redakcji: listopad 2014

Przyjęto do druku: lipiec 2015 